\title{
SCALING SOCIAL VENTURES AN EXPLORATORY STUDY OF SOCIAL INCUBATORS AND ACCELERATORS
}

\author{
GUILLERMO CASASNOVAS \\ University of Oxford \\ Oxford, United Kingdom \\ guillermo.casasnovas@sbs.ox.ac.uk
}

\author{
ALBERT V. BRUNO \\ Santa Clara University \\ Santa Clara, California, U.S.A. \\ abruno@scu.edu
}

\begin{abstract}
This article addresses the specific role of programs that attempt to help social ventures scale. We utilize combined experience in the Momentum Project from ESADE Business School and the Global Social Benefit Incubator at Santa Clara University, as well as an exploratory study of 40 social incubator and accelerator programs around the world, to frame the issues. We make a comparison among different programs and classify them as social incubators and social accelerators according to targeted social ventures and portfolio of resources offered. We note opportunities for research on social entrepreneurship and discuss relevant issues for both academics and practitioners such as the structure of these programs, the variance of approaches, and the resources needed by social ventures in their scaling processes.
\end{abstract}

Acknowledgements. We wish to acknowledge the support of a Willem and Maria Roelandts grant through the Center for Science, Technology, and Society at Santa Clara University. We also would like to express our appreciation to Lucas Flagg, who provided invaluable research support, to Thane Kreiner and an anonymous reviewer for their useful comments and suggestions, and to Marc Ventresca for his continued mentorship. Finally, 
our gratitude to the Global Social Benefit Incubator at Santa Clara University and the Momentum Project at ESADE Business School for providing the contexts for our research and learning.

\section{INTRODUCTION}

Social entrepreneurship appears when companies, charities, and governments fail in their attempts to correct social dysfunction. Sadly, that situation is the case for many global problems. Climate change remains unaddressed to a great extent, extreme poverty still affects billions of people, access to water and deforestation are becoming huge concerns in many parts of the world, unemployment is especially acute among many groups in developed countries, working conditions in some developing countries are far from being decent and fair, and many other problems are not being addressed effectively.

Where markets fail, social entrepreneurs often conceive of business models that look beyond profit maximization; where NGOs fail, social entrepreneurs design more efficient organizations; where governments fail, social entrepreneurs seek the same common good but with less bureaucratic and more flexible initiatives. Therefore, we can say that social entrepreneurship is at the intersection of social mission, market orientation and innovation (Nicholls, 2006).

In the last 15 years, the "fresh air" that social entrepreneurship has brought to the tackling of local, national, and global social challenges has precipitated increased interest among the social sector, academia, governments, media, and corporations. One of the topics that has been on the table from the beginning-since Ashoka travelled around India, Indonesia, and Brazil to support innovative community leaders in improving their projects (Bornstein, 2004) - has been scaling social ventures. The reason is clear: innovative solutions usually start in a local area, but as problems are often more global, replicating successful initiatives in other settings is often an attractive scaling strategy.

However, since successful scaling is not easy and the scaling process is not obvious, many institutions are dedicating their efforts to help social ventures increase their social impact. Embracing terminology from the commercial sector, so-called Social Incubators and Social Accelerators have emerged. These programs have experienced a significant boom in the past few years, appearing all over the world and in many different forms. 
The purpose of this article is to launch a preliminary study of social incubators and accelerators as important actors in the scaling processes of social ventures and the development of the social entrepreneurship sector in general. Our intention is to initiate a process of bringing order and structure to an emerging field that heretofore has been growing rather randomly. Ultimately, we envision a "best practices" approach to the field. From the point of view of academic research, we want to ground this subfield in the intersection of scaling strategies and social entrepreneurship because we think that an empirical investigation of these programs can bring valuable insights to both. An overview of the entrepreneurship and strategy literature will provide some insights as to how new ventures grow, especially those that do not seek profit maximization. Similarly, a review of the emerging social entrepreneurship literature will provide a better understanding of the nature of social enterprises as a growing set of actors in the global economy.

Our perspective is that of both academics and practitioners, since each author has been involved in both endeavors. The Global Social Benefit Incubator (GSBI) of Santa Clara University has been one of the pioneering and most influential programs in the sector. Starting in 2003, the GSBI has supported over 200 social entrepreneurs from around the world, with both online and in-residence training from the heart of Silicon Valley. Questions about what resources are most needed for social ventures, how to scale the GSBI itself, and how to build a global network of social incubators have carried the institution forward.

The Momentum Project, sponsored by ESADE Business School and global bank BBVA in collaboration with the international accounting firm PWC, is also a one-of-a-kind program. Started in the midst of the Spanish financial and economic crisis, the Momentum Project is an example of collective learning and support for the social entrepreneurship ecosystem. It is also one of the few social accelerators that include direct funding for successful participants. The Momentum Project reaches social entrepreneurs, students, professors, bankers, managers, and many more, and it has crossed the Atlantic to launch new editions of the program in Latin America in order to foster social entrepreneurship in that region.

The first-hand experiences that we have garnered in both GSBI and the Momentum Project provide the context for this study. We start by framing the topic within the social entrepreneurship and scaling literature. We then describe the methods that we used to scan the rapidly expanding field and the results that we found. Finally, we discuss these findings and conclude with ten propositions that reflect our view of how academic research can address the topic of social incubators and 
accelerators. We conclude with some suggestions and implications for practitioners interested in the sector.

\section{SOCIAL ENTREPRENEURSHIP}

As a field of inquiry, social entrepreneurship has grown rapidly during the past 15 years; this growth has resulted in more attention from governments (Nicholls, 2010; Sud, Vansandt, \& Baugous, 2009), corporations (Prahalad, 2006; Yunus, 2009), academics (Dacin, Dacin, \& Matear, 2010; Short, Moss, \& Lumpkin, 2009), and business schools. See for example the Academy of Management Learning and Education series of interviews with well-known strategy expert Michael Porter (Driver, 2012), social entrepreneurship scholar Gregory Dees (Worsham, 2012), successful social entrepreneur Sara Harris (Plaskoff, 2012), and social entrepreneur and Nobel laureate Muhammad Yunus (Kickul, Terjesen, Bacq, \& Griffiths, 2012). From an academic point of view, this interest has translated into a growing number of papers in refereed management journals (Granados, Hlupic, Coakes, \& Mohamed, 2011; Short et al., 2009).

A number of researchers have attempted to develop a generallyaccepted definition of social entrepreneurship or set the boundaries of the field. For example, six books published on the subject in 2006 (Austin, Gutierrez, Ogliastri, \& Reficco, 2006; Mair, Robinson, \& Hockerts, 2006; Mosher-Williams, 2006; Nicholls, 2006; Nyssens, 2006; Perrini, 2006) offered several conceptual frameworks. Zahra et al. (2009) sought an integrated definition, stating it as: "Social entrepreneurship encompasses the activities and processes undertaken to discover, define, and exploit opportunities in order to enhance social wealth by creating new ventures or managing existing organizations in an innovative manner." Dacin et al. (2010) find that definitions of social entrepreneurship tend to converge on four key factors: characteristics of individual social entrepreneurs, operating sector, processes and resources used, and primary mission and outcome. The definitions of social entrepreneurship and a social venture have direct implications for how we view social incubators and social accelerators and hence how organizations are classified in our exploratory study.

In general, there are three areas of debate among scholars and practitioners about how to define social entrepreneurship:

- $\quad$ Broad vs. Narrow definition. Although a number of scholars use broad definitions wherein social entrepreneurship is at the intersection of social impact, innovation, and mar- 
ket orientation (Nicholls, 2006), the challenge, as Paul C. Light (2008) reflects on his own description, is that "the problem with my more inclusive definition of social entrepreneurship is clear: suddenly social entrepreneurship can be found almost everywhere."

- Individual vs. Collective emphasis. While early studies were based on the work of individual social entrepreneurs who wanted "to change the world" (Bornstein, 2004), over the years there has been a shift toward focusing on organizations and processes (Mair \& Martí, 2006) and more recently even toward the concept of "collective social entrepreneurship" (Montgomery, Dacin, \& Dacin, 2012).

- Not-for-profit vs. For-profit organizations. On this dimension, there is a large range of interpretations-from researchers who consider only not-for-profit organizations to be social enterprises to others who consider all for-profit companies with a social mission to be social ventures. In general, most scholars do not look at the organizational form but whether the social mission is central to the organization.

While there is no "right" or "wrong" definition, and because it will be difficult to find a unifying paradigm until the field is more mature, it is important for research and analytic purposes that academics, institutions, and, of course, social ventures explicitly identify the basic principles to which they aspire. Such clarity will help investors and other interested parties know beforehand what they can and cannot expect in each case, as well as how to evaluate the claims made or the scope for potential policy applications.

For the purposes of this research, we use a definition of social entrepreneurship that conceptualizes the field rather broadly, which focuses on the activity rather than on the individual or organization form, and which, although putting the social mission at the center (Dees 1998; Dacin, Dacin, \& Tracey, 2011: 1204), does not require a particular profit perspective. Therefore, we will define social entrepreneurship as the practice of targeting social challenges with innovative and market-oriented solutions, and social ventures as those organizations that primarily target social challenges through innovative and market-oriented solutions. 


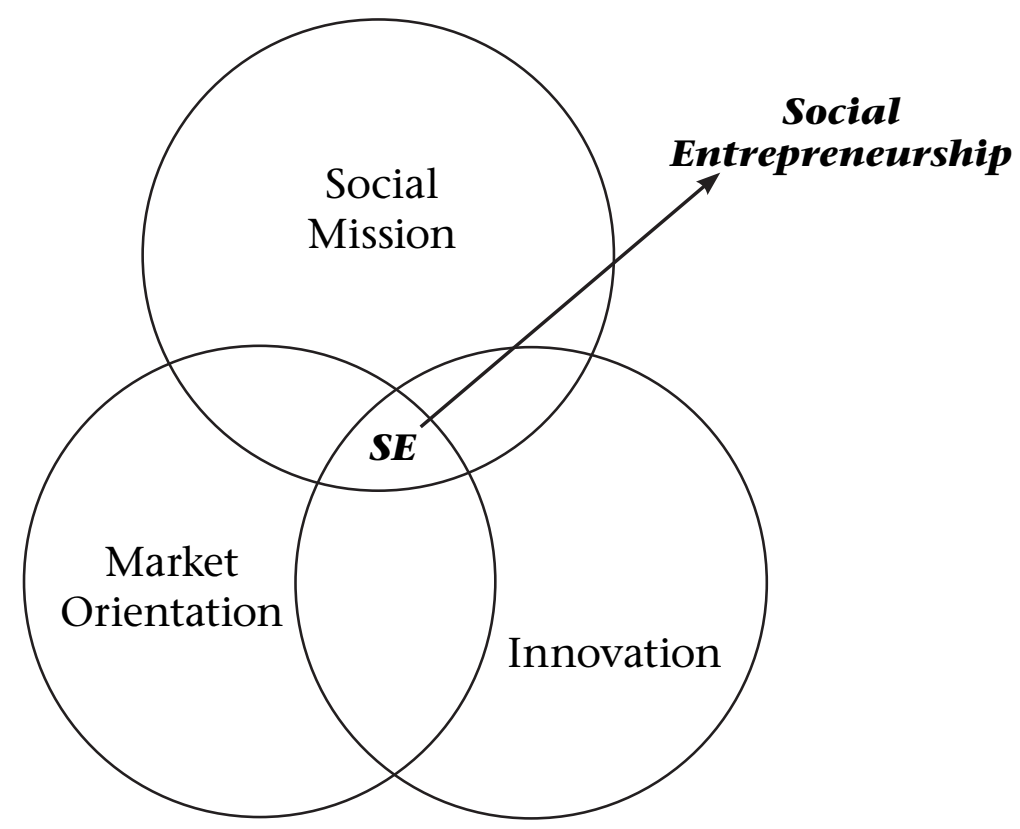

Figure 1: Domain of Social Entrepreneurship

\section{SCALING}

A topic that has attracted increasing attention among scholars writing about social entrepreneurship is scaling, or the process of achieving a wider social impact. It is interesting to note that, among social entrepreneurs, the concept of scaling usually refers not to the size of the organization but to the scope or magnitude of the expected social impact. As Bloom and Chatterji observe, social ventures pursue scaling “... because they want to have as big an impact as possible on social problems and because their donors and supporters are hungry to achieve high 'social' returns on their investments" (2009: 115).

The investigation of social impact scaling had previously focused on non-profits (Bardach, 2003) and social innovation (Dees, Anderson, \& Wei-Skillern, 2004), but Bloom's model of SCALERS (Bloom \& Chatterji, 2009; Bloom \& Smith, 2010) demonstrates the relevance of this subject for social entrepreneurial organizations. Indeed, as the social challenges addressed by social ventures are usually large, complex and wicked (Dorado \& Ventresca, 2013), scaling becomes a matter of utmost importance. In this sense, it is meaningful that the Unreasonable Institute, an organization that supports social ventures, states that its goal 
is "to accelerate these ventures so they can scale to meet the needs of at least one million people each." 1 Also remarkable is Ashoka's definition of a social entrepreneur: “(...) they are ambitious and persistent, tackling major social issues and offering new ideas for wide-scale change" 2 (emphasis added by the authors in both cases). Again, the figure of 4 billion people who live on less than US\$2.50 a day and are the ultimate goal of those social ventures targeting the "base of the pyramid" (Prahalad, 2006) shows the ambition of reaching a large scale with social entrepreneurial projects.

At the local level, social ventures want to scale their projects so that problems can be tackled at a wider regional level. Take for example Anna Cohí, President and Co-founder of DAU, one of the social entrepreneurs who took part in the first edition of the Momentum Project. When she was presenting DAU's business plan to a group of potential investors, she shared a shocking statistic: in the city of Barcelona, where ESADE is located, 3,362 of the 11,207 people who suffer from Severe Mental Disorders (SMD) are capable of holding a job and earning an income. However, only 450 of these 3,362 actually have a job because too few companies offer employment for people with SMD and the companies that do offer employment are too small to make an impact on the number of those employable individuals. This situation translates to an unemployment rate of $87 \%$, which DAU is trying to lower; doing so was the focus of DAU's participation in the Momentum Project, reflected in a determined growth strategy and its need of funds to achieve it.

The issue of scaling social ventures is indeed a difficult challenge. As former United States President Bill Clinton observed: "Nearly every problem has been solved by someone, somewhere. The challenge of the 21st century is to find out what works and scale it up." ${ }^{3}$ Part of the challenge of scaling is connected to the ecosystems in which social ventures operate (Bloom \& Dees, 2008; Sharir \& Lerner, 2006; Vernis \& Navarro, 2011). Other actors such as media, governments and financial institutions will have direct effect on the success and growth opportunities in the social entrepreneurship world. The seven "situational contingencies" stated in Bloom and Chatterji's (2009) SCALERS model-(1) labor needs, (2) public support, (3) potential allies, (4) supportive public policy, (5) start-up

${ }^{1}$ Unreasonable Institute-What We Do, http://unreasonableinstitute.org/2013institute (accessed April 16, 2013).

${ }^{2}$ Ashoka-What is a Social Entrepreneur, https://www.ashoka.org/social_ entrepreneur (accessed April 16, 2013).

${ }^{3} \mathrm{http}: / /$ www.americanprogress.org/issues/open-government/ report/2010/07/01/8053/scaling-new-heights/ (accessed May 13, 2013). 
capital, (6) dispersion of beneficiaries, and (7) availability of economic incentives-can be viewed as elements of this broad ecosystem.

This systemic approach to social entrepreneurship is complemented by a resource-based view of the firm (Barney, 1991). For example, Meyskens et al. (2010) showed how successful social entrepreneurs take advantage of resources such as partnerships, financial capital, innovativeness, organizational structure, and knowledge transferability, suggesting that, "when viewed through a resource-based lens, [social entrepreneurs] demonstrate similar internal operational processes in utilizing resource bundles as commercial entrepreneurs" (p. 661). This resource-based view has also led to a focus on organizational capabilities, defined by Collis (1994) as "the socially complex routines that determine the efficiency with which firms physically transform inputs into outputs" (p.145).

As observed by Bloom and Smith (2010) when they tested the hypotheses of the SCALERS model, "Staffing, Communications, Alliancebuilding, Lobbying, Earnings generation, Replication, and Stimulating market forces" are organizational capabilities which are significantly correlated to the scaling of social ventures. Even though social entrepreneurs are resourceful people (Desa, 2011; Meyskens, Robb-Post, Stamp, Carsrud, \& Reynolds, 2010), many of their organizations do not have meaningful capabilities from the onset. This is a possible explanation for the emergence of support programs for social ventures, which have appeared in the last few years.

Little research has been conducted on this subject apart from the experience of incubating university students' social entrepreneurship ideas (Bloom \& Pirson, 2010) and a survey that is currently being carried out by the Aspen Network of Development Entrepreneurs (ANDE). For this reason, there is a need for exploratory academic research on the emergence of programs that support social venture scaling in order to clarify concepts, inform research on social entrepreneurship and the scaling of social impact, and offer meaningful insights to the increasing number of practitioners populating the field.

\section{METHODS}

Our definition of social ventures sets the boundaries for the identification of social incubators and accelerators-programs that support the scaling process of organizations that mainly target social challenges through innovative and market-oriented solutions. We differentiate these programs from other support institutions in that social incubators and 
accelerators offer a set of resources—not only a prize or award-and they usually work with cohorts rather than individual ventures. The resources offered often include training, mentoring, networking, or funding. We make no distinction as to the legal form of these support programs - they can be either for-profit or non-profit organizations, hybrid organizations, or belong to larger institutions such as universities, governments, or financial institutions.

As part of our efforts, we have participated in a larger data collection effort cosponsored by Santa Clara University, the Aspen Network of Development Entrepreneurs (ANDE), Social Capital Markets (SOCAP), and Village Capital. This exploratory study does not reflect this larger effort, currently underway, which will eventually identify and evaluate approximately 90 incubators and accelerators worldwide. Instead, we worked with a set of 40 incubators and accelerators for which we identified some basic features, including country of origin, starting date, length of the program, offerings, requirements, and metrics of success. Given that social venture incubation is a nascent field and that our purpose is to understand the variety of forms that these programs represent, we have approached the study from a global perspective instead of limiting it to a particular country or region.

Our experience in managing social incubators and accelerators has helped us identify "offerings" and "requirements" as the main features for describing and understanding how these programs work and to whom they are addressed. We shared our insight with other senior colleagues from the field and they agreed that these were useful ways to portray these programs. Given our purpose of examining a significant number of social incubators and accelerators being run worldwide (as of December, 2012), we started from our own knowledge base and, as noted, leveraged the networks of our contacts and their institutions. Finally, we looked at the programs' websites to make sure they all matched our definition. We present the findings of this exploratory study in the next section.

\section{RESULTS}

Using the two main dimensions identified to portray the programs that support the scaling of social ventures, we have defined a typology comprising two basic types: social incubators and social accelerators. As can be seen in Table 1, each type has a different set of offerings (i.e., resources provided) and a different set of requirements (i.e., targeted social ventures). 


\begin{tabular}{|c|c|c|}
\hline & Social Incubators & Social Accelerators \\
\hline \multicolumn{3}{|l|}{ REQUIREMENTS } \\
\hline Company registered & No & Yes \\
\hline Full time-employees & None or some & At least 2 \\
\hline Years of experience & $0-3$ & 3 or more \\
\hline \multicolumn{3}{|l|}{ RESOURCES } \\
\hline Training & Entrepreneurial skills & Management skills \\
\hline Mentoring & $\begin{array}{l}\text { Focused on Business } \\
\text { Model and initial } \\
\text { Business Plan }\end{array}$ & $\begin{array}{l}\text { Focused on growth } \\
\text { strategy }\end{array}$ \\
\hline Networking & $\begin{array}{c}\text { Other social } \\
\text { entrepreneurs and } \\
\text { broader ecosystem }\end{array}$ & $\begin{array}{c}\text { Other social } \\
\text { ventures and broader } \\
\text { ecosystem }\end{array}$ \\
\hline Access to Funding & Grants or Seed Capital & Debt or Equity \\
\hline
\end{tabular}

Table 1: Common traits of Social Incubators and Accelerators

The programs that we portray as social incubators generally focus on ventures in their early stages of development-less than three years of existence with no particular threshold of revenue turnover or number of employees, and, as they target the social entrepreneurs themselves, often it is not necessary that the organizational form of the venture has been officially declared. The resources offered by these incubators usually include training in entrepreneurial skills, mentoring focused on designing the business model and the business plan, networking with other social entrepreneurs and the broader ecosystems, and access to grants or seed capital.

The social accelerators target ventures with at least two full-time employees and a minimum amount of revenue, showing that the company has already been established and has been able to gain market traction for some years. As for the offerings, they usually include management training, strategic mentoring focused on growth strategies in their specific industry, networking with other actors of the social entrepreneurship ecosystem, and access to financial instruments like debt or equity.

These differences between social incubators and social accelerators are also reflected in Figure 2, which depicts the life cycle of a social venture. As can be seen, the former address social ventures in their early stages and attempt to help them with the first stages of their growth, while the latter target organizations with a proven business model and help them reach the scale to which they aspire. 


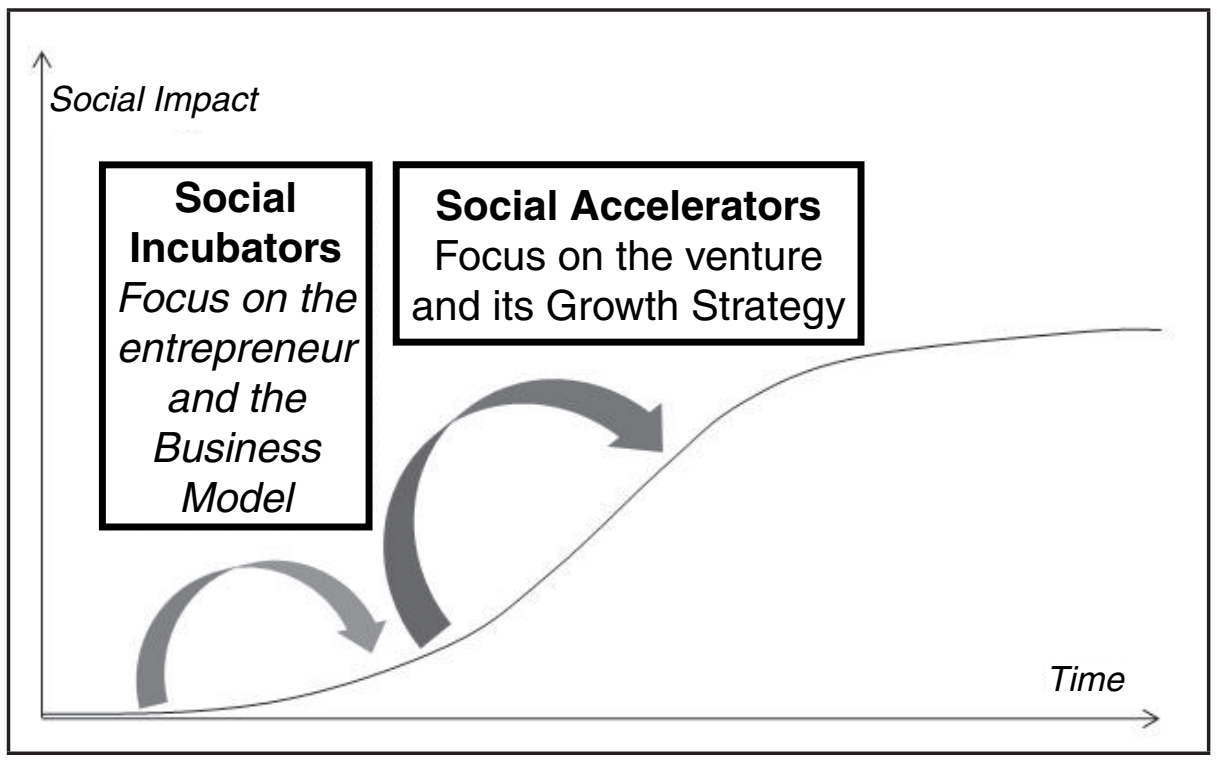

Figure 2: Support programs along the life cycle of social ventures

Appendix 1 contains the list of social incubators and accelerators identified, along with details about the nature of the organization (model of social lab), country of origin, and year of establishment.

\section{NASCENT FIELD}

The incubators and accelerators in our study ranged from one founded in 1987 to seven founded in 2012. The 1987 entity, Echoing Green, is a very early stage incubator focusing on less-than-2-year-old ventures wrestling with proof of concept. As can be seen in Figure 3, more than half (22 out of 40) of the incubators and accelerators have been founded in the last 4 years, with the median age of the ventures being 3.5 years. Thirty-seven of the 40 ventures have been founded in this century. Clearly, this is a nascent field.

\section{LENGTH OF PROGRAM}

The length of the program offered by the incubators and accelerators was also a variable of interest. Of the 40 programs examined, 21 reported program length on their respective websites. The programs ranged from 6 weeks to 2 years. There was significant variation in the reporting form 
for this variable, with some programs reporting only the total length of the program, and some including the specific in-residence time. Of the 21 reports, 11 indicated in-residence requirements of varying lengths. One aspect of this issue was the frequency of the in-residence sessions, some of which were a one-time "boot camp" while other in-residence programs took the form of several 2-day or 3-day modules during the duration of the program. The total in-residence time ranged from 1 to 8 weeks, but most of the programs are offering between 8 and 15 days of in-residence activity. Figures 4 and 5 summarize the reported program lengths.

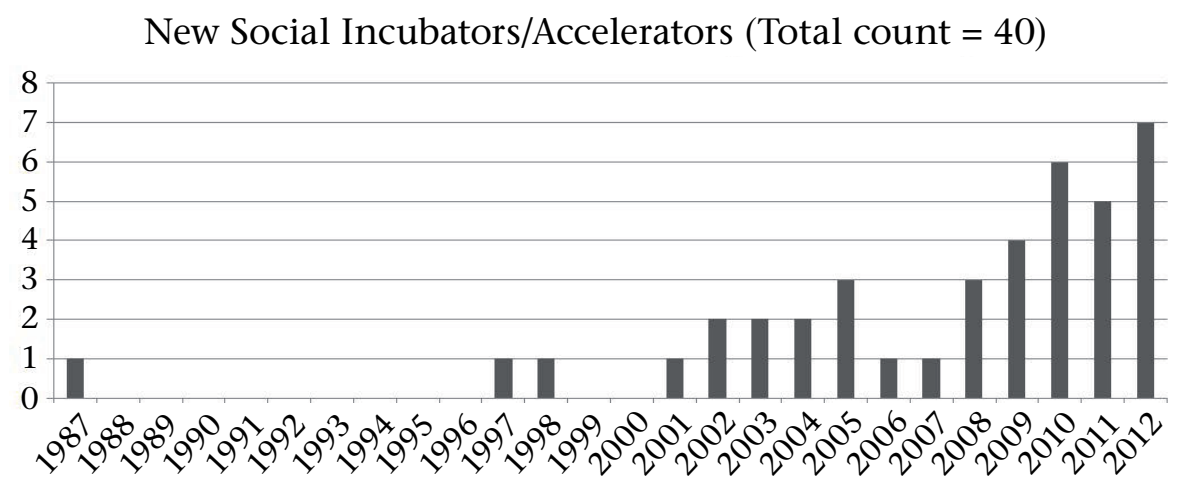

Figure 3: New social incubators/accelerators

Total Length of the Programs

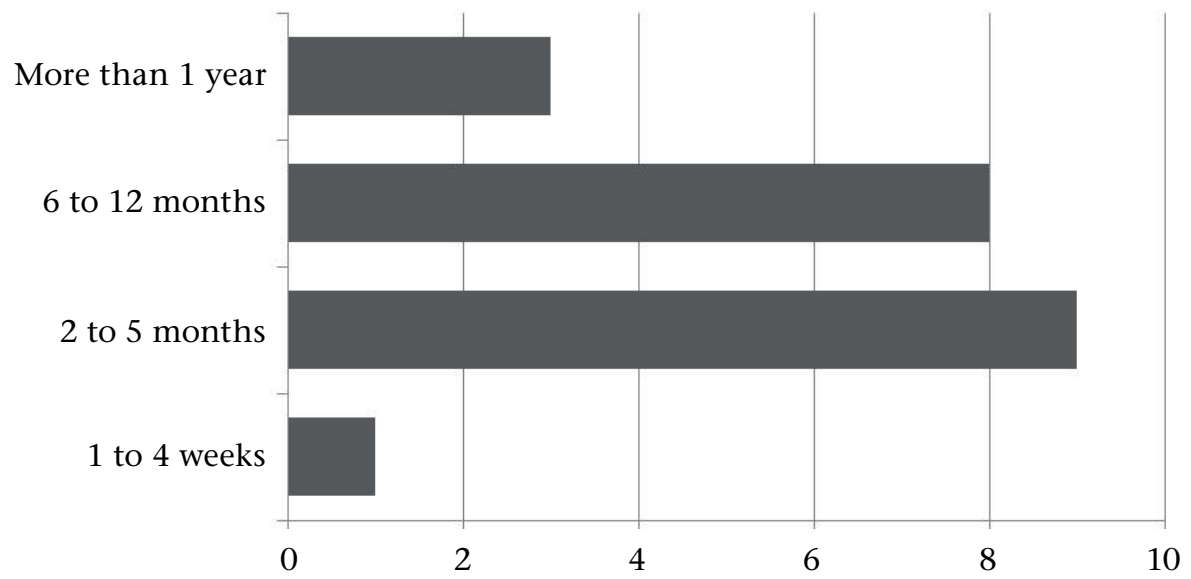

Figure 4: Total length of the programs 


\section{In-Residence Time of the Programs}

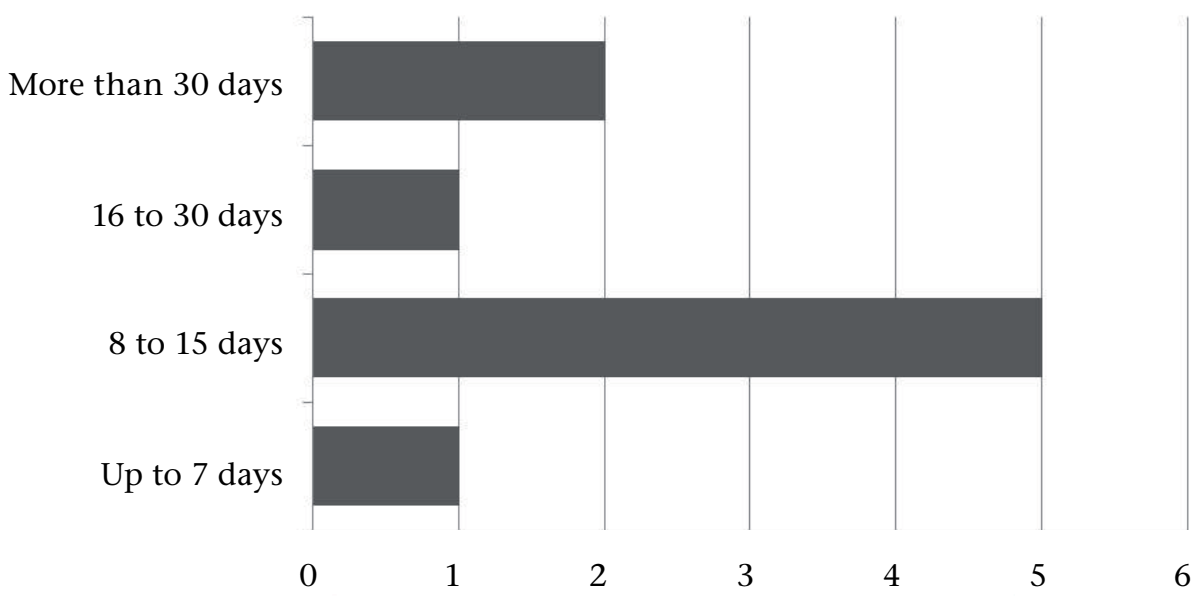

Figure 5: In-residence time of the programs

\section{METRICS}

Of the 40 incubators and accelerators that we examined, 13 reported some way or ways success was being measured. We considered each of these in turn with the hope of developing some insights from this level of investigation.

The first organization, Bid Network, which is a hybrid form, was launched in 2005, has 1500 annual candidates, and 30 annual participants. It measures success by a matching dollars metric ( $\$$ reported $=\$ 13$ million), number of businesses launched (673), and number of direct jobs created (4755).

The second organization, Echoing Green, an incubator founded in 1987, reports 20 annual participants selected from thousands of annual candidates. Echoing Green reports that two out of every three fellows achieve sustainability and on average are able to raise 37 times their seed funding over the next 5 years.

Emerge Venture Lab, a relatively new accelerator, has less than 10 annual participants. It reports that $60 \%$ are still operational and $45 \%$ raised funding after participation in the Emerge Venture Lab accelerator. 
Endeavor, an accelerator founded in 1998, reports that in the first two years after participating, its alumni enjoy an average annual growth rate of $59 \%$.

The Global Social Benefit Incubator, founded in 2003 as an incubator, will be transforming into an accelerator in 2013. It reports 15-20 annual participants selected from 150-300 annual applicants. Of its 168 alumni, 93\% are still operational and 55\% are scaling (defined as revenue growth exceeding cost/expense growth).

Hub Ventures, another accelerator, was founded in 2011 and reports 8-10 annual participants with $80 \%$ of alumni still operating.

The Momentum Project, founded in 2011 also as an accelerator, has 10 annual participants selected from 100 annual candidates. It reports that $65 \%$ have received funding.

NESST, a hybrid organization founded in 1997, reports 5 annual participants. Its success metrics include 3,928 trained in SE development, 58 SEs currently active and $\$ 8.09$ million invested to date.

The Propeller Social Venture Accelerator, self-described as a hybrid, was founded in 2012 and has 13-15 participants. It reports that the first 9 fellows generated $\$ 2.2$ million in external funding and created 40 new jobs.

UnLtd India, founded in 2007 as a hybrid organization, reports 3,200 jobs created with more than 650,000 beneficiaries.

The Unreasonable Institute, founded in 2010 as an accelerator, has 20-25 annual participants selected from 200-300 yearly applicants. It reports that $87 \%$ are still operating, and that $68 \%$ have raised funds.

Village Capital, founded in 2010 as an incubator, has 60 annual participants. It reports launching 13 programs and serving 250 social entrepreneurs who have created 500 jobs and served 8,000 customers.

Finally, Villgro (SEED), founded in 2002, has 10 annual participants. It reports 3,800 jobs created and 5 million individuals impacted.

While there is some similarity in the reporting, primarily in jobs created and sustainable efforts, there is clearly much variation as well.

There may be several reasons for this variation. Of course, the details of each institution's mission will vary a bit from the missions of the other 
institutions, as will its location, relevant environment, age, and so on, but it is certainly a symptom that the field is in an early stage. There is also no general consensus in the social entrepreneurship arena about how to measure the success or failure of social ventures. Concepts like the breadth and depth of impact (quantity versus quality) have to be taken into account; and, of course, utilizing numbers to measure social impact may make for easier comparisons, but it can sometimes lead to misleading conclusions when lasting social change is the objective rather than shortterm fixes. On the other hand, it is not easy for incubators and accelerators to create and maintain exhaustive and meaningful impact databases on the social enterprises that have participated in their programs. For some ventures, but not for others, job creation will be important. Some might shift toward an advocacy focus because they think that doing so will have more impact. Others may change from one form to another to take advantage of the expertise garnered in their earlier form.

Measures of success, however, are important not only for comparing different programs but also for program self-evaluation. Yet, it may be difficult for these incubators and accelerators to push their social venture participants toward measuring social impact if they themselves are not capably measuring their own social impact.

\section{CONCLUSIONS}

We have focused on identifying patterns and characteristics of social incubators and accelerators, with each cluster having a different set of attributes. Although we have been able to draw some insights from an examination of the data gathered on these support organizations, this is just the first stage of a larger, multi-phased study. As we have observed, this field is a nascent one, with more than half of the scrutinized programs started in the last four years. We have seen that there is significant variation in the total length of the programs (from some weeks to 2 years), with a small portion of the total length typically committed to in-residence time (most frequently between 8 and 15 days). We have also analyzed the metrics used by the different institutions, describing current trends and challenges of this particular topic.

It is worth noting that both the incubator-type and the acceleratortype of support programs are important and necessary for the development of social entrepreneurship and the effective scaling of social businesses. In fact, if it were not for these support organizations, some number of social ventures poised for major impact would fail in their early stages, well before they have the opportunity to scale. The crucial 
issue is that these two types of support organizations target different ventures and offer different resources. There are thousands of social entrepreneurs in many developed and developing countries not only with great ideas to "change the world," but also with the determination and resourcefulness that will guide them forward in their endeavors. What will be needed to increase the likelihood of success? Our list includes: to depict a sustainable business model, to receive some training in finance, strategy, marketing, and communication, to establish a network of contacts to help launch the initiative, and to find seed capital to back the new ventures' needs during their first stages.

Throughout the world, there are many social enterprises that have been laboring in the market economy for some years. These entrepreneurs may have different challenges if we compare them to the ones described above because they have already found a sustainable business model as well as the necessary funds to launch their social ventures. Given that these organizations are already in the scale-up process, it is reasonable to ask whether they will need different resources and services to succeed in their effort to increase their social impact. First, it is likely that business skills will be important—not only "entrepreneurial" skills but also those related to the main functional areas in a company-sales and marketing, finance, human resources, operations, etc. Second, access to mentoring should be another key resource. If mentoring for early-stage social entrepreneurs is usually focused on the business model and the business plan, mentoring for later-stage social ventures should address issues such as growth strategies or strategic alliances, and reinforce the whole team rather than solely focus on the individual entrepreneur. Third, as the organizations are older and larger, funding needs will usually be greater. However, as older social enterprises will not suffer from the so-called liability of newness (Stinchcombe, 1965; Stuart, Ha Hoang, \& Hybels, 1999), the risk will be reduced and financial instruments such as commercial or convertible loans could become available.

Given that majority of social incubators and accelerators are very young, the field is still evolving. Therefore, questions related to the boundaries, forms and strategies of these programs are still open. For example, social incubators and accelerators will have to decide what resources they will provide themselves with and what they will seek to provide via partnerships. Furthermore, do the resources that they offer match the actual needs of the social ventures, or are they a function of the support organization's capabilities? Will programs be better off if they are for-profit, not-for-profit, or hybrids? How should they be funded? The characteristics and needs of social entrepreneurs will be presumably 
different depending on the region in which they are operating. Do these differences raise questions about the efficacy of global programs?

We expect the field to evolve towards improved performance measurement frameworks, especially social impact metrics. Improved metrics will certainly help incubator and accelerator support organizations better achieve legitimization as necessary actors in the social entrepreneurship scene, as well as provide yardsticks for learning and practice improvement. Maintaining relationships with social ventures and sustaining some form of performance measurement after their participation in the programs will be essential to ensuring long-lasting impact. Finally, having networks of social incubators and accelerators, or even an industry association such as ANDE, will enable the sharing of best practices and the constructive comparison of programs. These factors will move the field forward.

These conclusions and open questions have been drawn from our work at GSBI and the Momentum Project, and from the online information we have gathered from other social incubators and accelerators. Table 2 provides information on GSBI and the Momentum Project. The next step will be to build a larger database with detailed information from these and other programs that support social ventures and to explore the adequacy of our classification and conclusions.

\section{FUTURE RESEARCH AND SUGGESTED ACTIONS}

In this portion of our article, we have combined our personal experience in the field with the information obtained by scanning the websites of the incubators and accelerators identified. We anticipate that future research will involve follow-on questionnaires and personal interviews, and will help us gain further understanding of these issues. Now we will state directions for future research in the form of propositions so that these can serve as a guide for academics and practitioners as to how the success of social incubators and accelerators can be enhanced.

We view programs that support social ventures in their growth processes as distinct organizations that are worthy of special attention. We also think that they have enough traits in common with each other to allow us to make observations about them as a nascent field.

Proposition 1: Social incubators and accelerators support organizations that combine market-oriented and innovative approaches to address social challenges. 
Social entrepreneurs who apply to these programs should understand that they will be expected to have a business focus and an innovative solution in combination with a scalable social mission.

\begin{tabular}{|c|c|c|}
\hline Program & $\begin{array}{c}\text { Global Social } \\
\text { Benefit Incubator }\end{array}$ & Momentum Project \\
\hline Institution(s) & Santa Clara University & ESADE Business School and BBVA \\
\hline First Edition & 2003 & 2011 \\
\hline $\begin{array}{l}\text { Annual } \\
\text { participant } \\
\text { social } \\
\text { ventures }\end{array}$ & 20 & 10 \\
\hline $\begin{array}{c}\text { Participants } \\
\text { from each } \\
\text { venture } \\
\end{array}$ & 1 & 2 \\
\hline \begin{tabular}{|c|}
$\begin{array}{c}\text { Length of the } \\
\text { program }\end{array}$ \\
\end{tabular} & 1 year ( 9 days in-residence) & 5 months (10 days in-residence) \\
\hline Reach & $\begin{array}{c}\text { A global edition } \\
\text { complemented with detailed } \\
\text { online mentoring to a larger } \\
\text { group }\end{array}$ & $\begin{array}{l}\text { Momentum currently has domestic } \\
\text { editions in Spain and Mexico }\end{array}$ \\
\hline Training & $\begin{array}{l}\text { Business models, business } \\
\text { planning, financing, human } \\
\text { resource development }\end{array}$ & $\begin{array}{c}\text { Sales, Finance, Communication, } \\
\text { Growth Strategies, Social Impact, } \\
\text { Human Resources }\end{array}$ \\
\hline Mentoring & $\begin{array}{c}\text { Provided by Silicon Valley } \\
\text { entrepreneurs, focused on } \\
\text { the business model and the } \\
\text { start-up phase }\end{array}$ & $\begin{array}{l}\text { Alumni from ESADE and managers } \\
\text { from BBVA, focused on the scale- } \\
\text { up process }\end{array}$ \\
\hline Finance & $\begin{array}{l}\text { Presentations to Venture } \\
\text { Capitalists }\end{array}$ & $\begin{array}{l}\text { Presentations at the Social } \\
\text { Investment Day and specific } \\
\text { financial instrument for } \\
\text { Momentum's social enterprises }\end{array}$ \\
\hline Classification & Social Incubator & Social Accelerator \\
\hline
\end{tabular}

Table 2: Comparison between GSBI and Momentum Project

Proposition 2: Social incubators and accelerators offer a portfolio of resources that usually combines training, mentoring, networking, and access to funding.

These resources are usually important for new social (and commercial) ventures, but some social entrepreneurs might need other types of support in their scaling process. 
Proposition 3: Social incubators and accelerators do not select ventures based on organizational form (for-profit, charity, limited liability, cooperative, hybrid, etc.).

The organizational form of the social venture is not expected to correlate with its performance, but support programs should include some training or advice regarding the range of available forms for social enterprises and the implications of these alternative forms for various activities (e.g., availability of financial sources). We can find different subsets of programs in the field depending on the origin of the sponsoring institution or the stage of the ventures addressed.

Proposition 4: The origin or the philosophy of the sponsoring institution (educational, financial, governmental) will often influence the operations and the set of resources offered by the program, making use of its expertise but also reinforcing its particular agenda.

Social ventures should apply to those programs that pay special attention to the resources which are important for their particular needs.

Proposition 5: Programs targeting early stage ventures (defined here as social incubators) will focus on the entrepreneurial skills of the social entrepreneurs, their business model and business plan, and grants or seed capital to start the company. Those targeting social enterprises older than three years (defined here as social accelerators) will focus on the business skills of the management team, the growth strategy, and capital (debt or equity) for the scale-up phase (see Table 1 above).

Although it might not be easy to measure the success of these programs, some of them are more effective in their efforts to make social ventures grow. Of course, many variables are at play, but we think that the most important ones are the selection process, access to funding, and partnerships.

Proposition 6: Those programs that exert more effort in carefully designed and expertly handled selection processes, open to a broad population and admitting those ventures that best fit into the program, will have higher rates of success.

The selection process is one of the key success factors of the programs. This activity should receive attention from both the support programs and those who apply to them.

Proposition 7: Those programs that offer specific funding channels to the participant social ventures will have higher rates of success. 
Funding is very important for most social ventures, and if they do not have access to it, their growth plans may be limited or even stuck in the bottom of desk drawers. This part of the program should be taken into account by all parties from the beginning-by making clear the responsibilities of the social incubators and accelerators, by introducing the entrepreneurs to prospective funders, possibly by certifying the viability of the participants of the program, and perhaps, by investing in the ventures themselves, etc.

Proposition 8: Those programs that dedicate time to establishing relationships and partnerships with other institutions, thus building an ecosystem, will have higher rates of success.

Social entrepreneurship is seldom a solo game. Not only is it important for social incubators and accelerators to be a part of, and help build, an ecosystem, but it is also important to have partners whose resources can be leveraged.

Proposition 9: If mentors are experienced entrepreneurs with a good understanding of social entrepreneurship and expertise in the industries where their mentored ventures are performing, they will be able to make better contributions to the success of the participants in the program.

Mentoring is important to the success of the programs, but it is not obvious how to address this need. In addition to assuring mentors' availability in terms of time devoted to the program, social incubators and accelerators should focus on recruiting and retaining mentors with entrepreneurial experience, industry expertise, some previous contact with social enterprises, senior management experience, and a commitment to establishing and sustaining a close and trusted relationship with the social entrepreneurs.

Proposition 10: As is usual in nascent industries, we expect that many suppliers (social incubators and accelerators) will appear and disappear until a "dominant design" of support programs becomes the standard.

There are now many different models for how social incubators and accelerators are organized, managed, and funded. As some models succeed and others fail, both financial and social expectations of the different models will have to be met. 


\section{SUMMARY}

The purpose of this article has been to initiate a systematic and analytical examination of the increasing number of programs that support the growth of social ventures. By linking this discussion to the scaling and social entrepreneurship literature, we have bridged what had been heretofore a practitioner-oriented field to the academic arena. Extensive and intensive research will be necessary in order to verify our propositions with more detailed data about these programs and their participants so as to better understand the role of social incubators and accelerators in the scaling process of social ventures. Our aim has also been to give some hints to social entrepreneurs about the possibilities that social incubators and accelerators can offer and how to make the most of them to enhance significant scaling and social impact.

\section{REFERENCES}

Austin, J. E., Gutierrez, R., Ogliastri, E., \& Reficco, E. (Eds.). 2006. Effective management of social enterprises: Lessons from businesses and civil society organizations in Iberoamerica. David Rockefeller Center for Latin American Studies.

Bardach, J. 2003. Going to scale: The challenge of replicating social programs. Stanford Social Innovation Review, 1: 19-25.

Barney, J. 1991. Firm resources and sustained competitive advantage. Journal of Management, 17(1): 99.

Bloom, G., \& Pirson, M. 2010. Supporting social change agents through the classroom: The SE lab model. Journal of Corporate Citizenship, 39: 103111.

Bloom, P. N., \& Chatterji, A. K. 2009. Scaling social entrepreneurial impact. California Management Review, 51(3): 114-133.

Bloom, P. N., \& Dees, G. 2008. Cultivate your ecosystem. Stanford Social Innovation Review, Winter.

Bloom, P. N., \& Smith, B. 2010. Identifying the drivers of social entrepreneurial impact: Theoretical development and an exploratory empirical test of scalers. Journal of Social Entrepreneurship, 1(1): 126-145.

Bornstein, D. 2004. How to change the world: Social entrepreneurs and the power of new ideas. Oxford University Press.

Collis, D. J. 1994. Research note: How valuable are organizational capabilities? Strategic Management Journal, 15: 143-152.

Dacin, M. T., Dacin, P. A., \& Tracey, P. 2011. Social entrepreneurship: A critique and future directions. Organization Science, 22(5): 1203-1213. 
Dacin, P. A., Dacin, M. T., \& Matear, M. 2010. Social entrepreneurship: Why we don't need a new theory and how we move forward from here. The Academy of Management Perspectives, 24(3): 37.

Dees, J. G. 1998. The Meaning of Social Entrepreneurship. Stanford University: Draft Report for the Kauffman Center for Entrpreneurial Leadership.

Dees, G., Anderson, B. B., \& Wei-skillern, J. 2004. Scaling social impact: Strategies for spreading social innovations. Stanford Social Innovation Review, Spring: 24-32.

Desa, G. 2011. Resource mobilization in international social entrepreneurship: Bricolage as a mechanism of institutional transformation. Entrepreneurship Theory and Practice, 36(4): 727-751.

Dorado, S., \& Ventresca, M. J. 2013. Crescive entrepreneurship in complex social problems: Institutional conditions for entrepreneurial engagement. Journal of Business Venturing, 28(1): 69-82.

Driver, M. 2012. An interview with Michael Porter: Social entrepreneurship and the transformation of capitalism. Academy of Management Learning \& Education, 11(3): 421-431.

Granados, M. L., Hlupic, V., Coakes, E., \& Mohamed, S. 2011. Social enterprise and social entrepreneurship research and theory. Social Enterprise Journal, 7(3): 198-218.

Kickul, J., Terjesen, S., Bacq, S., \& Griffiths, M. 2012. Social business education: An interview with Nobel Laureate Muhammad Yunus. Academy of Management Learning \& Education, 11(3): 453.

Light, P. C. 2008. The search for social entrepreneurship. Brookings Institution Press.

Mair, J., \& Martí, I. 2006. Social entrepreneurship research: A source of explanation, prediction, and delight. Journal of World Business, 41(1): 36-44.

Mair, J., Robinson, J., \& Hockerts, K. 2006. Social Entrepreneurship. Palgrave Macmillan.

Meyskens, M., Robb-Post, C., Stamp, J. A., Carsrud, A. L., \& Reynolds, P. D. 2010. Social ventures from a resource-based perspective: An exploratory study assessing global Ashoka Fellows. Entrepreneurship Theory and Practice, 34(4): 661-680.

Montgomery, A., Dacin, P., \& Dacin, M. 2012. Collective social entrepreneurship: Collaboratively shaping social good. Journal of Business Ethics, 111(3): 375-388.

Mosher-Williams, R. 2006. Research on social entrepreneurship: Understanding and contributing to an emerging field, vol. 1(3). ARNOVA.

Nicholls, A. 2006. Social entrepreneurship: New models of sustainable social change. Oxford University Press, USA.

Nicholls, A. 2010. Institutionalizing social entrepreneurship in regulatory space: Reporting and disclosure by community interest companies. Accounting, Organizations \& Society, 35(4): 394-415. 
Nyssens, M. (Ed.). 2006. Social enterprise: At the crossroads of market, public policies and civil society. Routledge.

Perrini, F. (Ed.). 2006. The new social entrepreneurship: What awaits social entrepreneurship ventures? Edward Elgar Pub.

Plaskoff, J. 2012. Building the heart and the mind: An interview with leading social entrepreneur Sarah Harris. Academy of Management Learning \& Education, 11(3): 432.

Prahalad, C. K. 2006. Fortune at the bottom of the pyramid: Eradicating poverty through profits. Dorling Kindersley Pvt Ltd.

Sharir, M., \& Lerner, M. 2006. Gauging the success of social ventures initiated by individual social entrepreneurs. Journal of World Business, 41(1): 6-20.

Short, J., Moss, T., \& Lumpkin, G. 2009. Research in social entrepreneurship: Past contributions and future opportunities. Strategic Entrepreneurship Journal, 3: 161-194.

Stinchcombe, A. L. 1965. Social structure and organizations. In J. March (Ed.), Handbook of Organizations: 142-193. Chicago: Rand McNally.

Stuart, T. E., Ha Hoang, \& Hybels, R. C. 1999. Interorganizational endorsements and the performance of entrepreneurial ventures. Administrative Science Quarterly, 44(2): 315-349.

Sud, M., Vansandt, C. V., \& Baugous, A. M. 2009. Social entrepreneurship: The role of institutions. Journal of Business Ethics, 85: 201-216.

Vernis, A., \& Navarro, C. 2011. El concepto de ecosistema para el emprendimiento social. Revista Española del Tercer Sector, 17.

Worsham, E. L. 2012. Reflections and insights on teaching social entrepreneurship: An interview with Greg Dees. Academy of Management Learning \& Education, 11(3): 442.

Yunus, M. 2009. Creating a world without poverty: Social business and the future of capitalism, reprint. PublicAffairs.

Zahra, S. A., Gedajlovic, E., Neubaum, D. O., \& Shulman, J. M. 2009. A typology of social entrepreneurs: Motives, search processes and ethical challenges. Journal of Business Venturing, 24(5): 519-532.

\section{APPENDIX 1: LIST OF SOCIAL INCUBATORS AND SOCIAL ACCELERATORS ANALYZED}

\begin{tabular}{|c|c|c|c|c|}
\hline$\#$ & Name & $\begin{array}{c}\text { Geographic } \\
\text { Origin }\end{array}$ & $\begin{array}{c}\text { First } \\
\text { Year }\end{array}$ & Type \\
\hline 1 & Agora Partnerships & Nicaragua & 2011 & Accelerator \\
\hline 2 & Antropia & France & 2005 & Incubator \\
\hline 3 & Antropia Scale-Up & France & 2005 & Accelerator \\
\hline 4 & Artemisia & Brazil & 2010 & Accelerator \\
\hline 5 & Ashden Awards & UK & 2001 & Hybrid \\
\hline
\end{tabular}




\begin{tabular}{|c|c|c|c|c|}
\hline 6 & Bid Network & Netherlands & 2005 & Hybrid \\
\hline 7 & Change Fusion Nepal & Nepal & 2009 & Hybrid \\
\hline 8 & Dasra Social-Impact & India & 2006 & Accelerator \\
\hline 9 & Echoing Green & USA & 1987 & Incubator \\
\hline 10 & Emerge Venture Lab & UK & 2010 & Incubator \\
\hline 11 & Endeavor & USA & 1998 & Accelerator \\
\hline 12 & Enviu & Netherlands & 2009 & Incubator \\
\hline 13 & Fledge & USA & 2012 & Incubator \\
\hline 14 & $\begin{array}{c}\text { Global Social Benefit } \\
\text { Incubator }\end{array}$ & USA & 2003 & Accelerator \\
\hline 15 & Good Company & USA & 2009 & Accelerator \\
\hline 16 & Hub Ventures & USA & 2011 & Accelerator \\
\hline 17 & iHub & Kenya & 2010 & Incubator \\
\hline 18 & $\begin{array}{c}\text { InfoDev “Creating } \\
\text { Sustainable Business" }\end{array}$ & Global & 2009 & Hybrid \\
\hline 19 & Inotek & Indonesia & 2008 & Hybrid \\
\hline 20 & $\begin{array}{c}\text { Intellecap } \\
\text { (Sankalp Forum) }\end{array}$ & India & 2008 & Accelerator \\
\hline 21 & $\begin{array}{c}\text { Invest2Innovate } \\
\text { (i2i Accelerator) }\end{array}$ & Pakistan & 2011 & Accelerator \\
\hline 22 & Israel Venture Network & Israel & 2004 & Accelerator \\
\hline 23 & $\begin{array}{c}\text { La CaixaEmprenedoria } \\
\text { Social }\end{array}$ & Spain & 2012 & Incubator \\
\hline 24 & Momentum Project & Spain & 2011 & Accelerator \\
\hline 25 & NESST & Lat Am \& Cent & 1997 & Hybrid \\
\hline 26 & New Ventures Mexico & Mexico & 2004 & Accelerator \\
\hline 27 & Panzanzee & USA & 2012 & Incubator \\
\hline 28 & Pop Tech & USA & 2008 & Accelerator \\
\hline 29 & Praxis & USA & 2010 & Accelerator \\
\hline 30 & $\begin{array}{c}\text { Propeller Social Venture } \\
\text { Accelerator }\end{array}$ & USA & 2012 & Hybrid \\
\hline 31 & Rock Health & USA & 2011 & Hybrid \\
\hline 32 & $\begin{array}{c}\text { The Ateneo Incubator } \\
\text { Program }\end{array}$ & Philippines & 2012 & Incubator \\
\hline
\end{tabular}




\begin{tabular}{|l|c|c|c|c|}
\hline 33 & The Impact Engine & USA & 2012 & Accelerator \\
\hline 34 & UnLtd India & India & 2007 & Hybrid \\
\hline 35 & UnLtd Ventures & UK & 2002 & Hybrid \\
\hline 36 & Unreasonable Institute & USA & 2010 & Accelerator \\
\hline 37 & Village Capital & USA & 2010 & Incubator \\
\hline 38 & Villgro & India & 2002 & Incubator \\
\hline 39 & $\begin{array}{c}\text { William James } \\
\text { Foundation }\end{array}$ & USA & 2003 & Incubator \\
\hline 40 & $\begin{array}{c}\text { Young Foundation- } \\
\text { The Accelerator }\end{array}$ & UK & 2012 & Accelerator \\
\hline
\end{tabular}

